Jurnal Akuntansi Indonesia, Vol. 9 No. 2 Juli 2020, Hal. 182 - 194

\title{
Faktor yang Mempengaruhi Minat Investasi Di Pasar Modal: Pendekatan Theory Of Planned Behaviour (TPB)
}

\author{
Naila Rizki Salisa \\ Program Studi Akuntansi, Fakultas Ekonomi dan Bisnis, Universitas Muria Kudus \\ naila.rizki@umk.ac.id
}

\begin{abstract}
The investment intention is important to be explored because intention to invest in Indonesian capital market is still low. This study analyze the factors that influence investment intention by using Theory of Planned Behaviour (TPB). Through TPB, investment intention can be measured from explanatory variables which in turn will encourage actual behaviour. The variables used to predict investment intention are attitudes, subjective norms, perceived behavioural control, financial literacy, and risk perception. This study uses 161 respondents that were collected through a questionnaire. Data were analyzed with validity, reliability, and hypothesis testing using Structural Equation Modeling (SEM) through path analysis method. The results show that attitudes and subjective norms have no significant effect on investment intention. Meanwhile, perceived of behavioural control, financial literacy, and risk perception have a positive effect on investment intention in the Indonesian capital market. This results are expected to contribute for future research and provide advice to the government to design programs that can increase investment intention in the capital market.
\end{abstract}

Keywords: Investment Intention, Theory of Planned Behaviour (TPB), Financial Literacy, Risk Perception

\begin{abstract}
ABSTRAK
Rendahnya minat investasi di pasar modal Indonesia menjadi isu yang menarik untuk dikaji lebih lanjut. Penelitian ini bertujuan untuk menganalisis faktor-faktor yang dapat mempengaruhi minat investasi di pasar modal dengan menggunakan pendekatan Theory of Planned Behaviour (TPB). Melalui TPB, minat investasi dapat diukur dari variabel penjelas yang pada akhirnya akan mendorong terciptanya perilaku aktual. Variabel yang digunakan untuk memprediksi minat investasi adalah sikap, norma subjektif, persepsi kendali perilaku, literasi keuangan, dan persepsi risiko. Data penelitian dikumpulkan melalui kuesioner dengan jumlah sampel sebanyak 161 responden. Data yang diperoleh diuji validitas, reliabilitas, dan uji hipotesis menggunakan Structural Equation Modelling (SEM) melalui metode analisis jalur. Hasil pengujian menunjukkan bahwa sikap dan norma subjektif tidak berpengaruh terhadap minat investasi. Sedangkan persepsi kendali perilaku, literasi keuangan, dan persepsi risiko berpengaruh positif terhadap minat investasi di pasar modal Indonesia. Hasil penelitian diharapkan dapat memberikan sumbangan pemikiran untuk penelitian selanjutnya dan dapat memberikan saran kepada pemerintah untuk merancang program yang dapat meningkatkan minat investasi di pasar modal.
\end{abstract}

Kata kunci: Minat Investasi, Theory of Planned Behaviour (TPB), Literasi Keuangan, Persepsi Risiko 


\section{PENDAHULUAN}

Jumlah investor pasar modal di Indonesia mengalami peningkatan setiap tahunnya. Sampai dengan April 2019, Kustodian Sentral Efek Indonesia mencatat terjadi peningkatan penggunaan Single Investor Identification (SID) sebesar 107,89\% menjadi 1.858 .803 investor dibandingkan tahun sebelumnya 894.116 investor pada tahun 2016 (KSEl, 2019). Akan tetapi, jumlah investor ini masih sangat rendah dibandingkan dengan populasi penduduk Indonesia (BPS, 2019) artinya jumlah investor di Indonesia berkisar 0,7\% dari populasi penduduk. Jumlah ini juga masih rendah jika dibandingkan dengan investor di negara lain, seperti Malaysia sebesar 57\% dari populasi, Cina 9\%, Thailand, 6\%, dan India 4\% (Narsa, et al., 2020).

Otoritas Jasa Keuangan (OJK) mengadakan Survei Nasional Literasi dan Inklusi Keuangan (SNLIK) tahun 2019 yang menunjukkan bahwa literasi keuangan di Indonesia meningkat dari tahun sebelumnya menjadi 38,03\% dan inklusi keuangan menjadi 76,19\%. Namun faktanya, literasi dan inklusi keuangan yang paling rendah terdapat pada sektor pasar modal yaitu hanya sebesar 4,92\% untuk literasi dan 1,55\% untuk inklusi. Hal ini menjadi isu yang menarik untuk dieksplorasi lebih lanjut karena hasil survei mengindikasikan bahwa minat individu untuk berinvestasi di pasar modal masih tergolong sangat rendah.

Penelitian sebelumnya terkait dengan minat investasi berfokus pada faktor eksternal seperti, ekspektasi imbal hasil dan risiko (Hoffmann, et. al., 2015); citra perusahaan (Ackert, et. al., 2010; Aspara, 2013); budaya (Daneshvar, et al., 2017); dan Corporate Social Responsibility (Cohen, et al., 2017). Berbeda dengan penelitian sebelumnya, penelitian ini termotivasi untuk menyoroti faktor internal yang dapat mempengaruhi minat individu untuk melakukan investasi di pasar modal. Individu memiliki asumsi jika keputusan mereka logis dan rasional. Namun ketika dihadapkan pada investasi, seringkali keputusan mereka didasarkan pada intuisi dan perasaan sehingga keputusan yang diambil tidak rasional karena terjadi bias dalam proses pengambilan keputusan (Combrink \& Lew, 2019). Sehubungan dengan bias perilaku, terbukti bahwa investor mengalami gambler's fallacy, hallo effect, dan familiarity effect (Djojopranoto \& Mahadwartha, 2016), overconfidence, framing effect (Combrink \& Lew, 2019), bias kognitif, dan bias emosi (Pradhana, 2018) yang mempengaruhi perilaku investor secara signifikan. Dengan demikian, menjadi penting untuk diteliti faktor-faktor internal individu yang mendasari minat individu untuk investasi di pasar modal.

Faktor internal memiliki pengaruh signifikan untuk menjelaskan minat investasi. Minat investasi dimanifestasikan sebagai seberapa besar individu memiliki keinginan untuk mencoba dan besar usaha yang direncanakan, yang pada akhirnya akan terwujudkan pada perilaku aktual dalam berinvestasi (Ajzen, 1991). Dalam penelitian ini, faktor internal yang mempengaruhi minat investasi dijelaskan melalui pendekatan Theory of Planned Behaviour (TPB). TPB yang dikemukakan oleh Ajzen (1991) menjelaskan minat untuk berperilaku dapat diprediksi dengan akurat melalui tiga komponen penting yaitu sikap, norma subjektif, dan persepsi kendali perilaku.

Sikap memiliki pengaruh yang signifikan terhadap minat investasi karena individu mengutamakan sikap ketika memutuskan untuk berinvestasi (Phan \& Zhou, 2014). Interaksi sosial dan tekanan sosial merupakan faktor utama yang mempengaruhi minat investasi karena adanya dorongan orang-orang terdekat (Akhtar \& Das, 2018). Disisi lain, kemudahan dalam investasi sebagai akibat dari adanya pengalaman dan pengetahuan 
mendorong individu untuk selalu melakukan investasi di pasar modal (Ashidiqi \& Arundina, 2017). Melalui TPB, tidak hanya menyoroti faktor internal namun juga faktor sosial dan kontrol keperilakuan yang diprediksi dapat mempengaruhi minat individu, khususnya dalam investasi. Umumnya, semakin menguntungkan sikap dan norma subjektif sehubungan dengan perilaku dan semakin besar persepsi kendali perilaku, semakin kuat minat individu untuk melakukan perilaku yang dipertimbangkan (Ajzen, 1991; Akhtar \& Das, 2018).

Dalam rangka meningkatkan daya prediksi penggunaan TPB, diperlukan penambahan konstruk yang dapat mengukur minat investasi, seperti literasi keuangan dan persepsi risiko (Alleyne \& Broome, 2011; Allgood \&Walstad, 2016). Hasil penelitian Allgood \&Walstad (2016) menemukan bahwa literasi keuangan yang tinggi memiliki pengaruh terhadap minat investasi di pasar modal. Namun, hasil penelitian Pradhana (2018) menemukan jika literasi keuangan tidak memiliki pengaruh terhadap minat investasi. Selain itu, Sokolowska \& Makowiec (2017) menemukan jika persepsi risiko individu terkait dengan investasi memiliki pengaruh yang negatif terhadap minat investasi karena disesuaikan dengan kondisi pasar. Hal ini berbeda dengan penelitian Alleyne \& Broome (2011) yang menemukan bahwa seorang individu akan meningkatkan persepsi atas risikonya jika berhadapan dengan keputusan investasi. Melalui perbedaan hasil penelitian tersebut memberikan peluang untuk penelitian ini mengkaji lebih lanjut dengan menambahkan literasi keuangan dan persepsi risiko yang dapat mempengaruhi minat investasi di pasar modal.

Literasi keuangan dan persepsi risiko memainkan peran yang penting dalam memprediksi minat investasi yang termanifestasikan pada keputusan untuk investasi (Hoffmann, et al., 2013; Listyani, et al., 2019). Keputusan untuk investasi berasosiasi dengan tingkat risiko. Penting bagi individu untuk memahami risiko masing-masing instrumen yang ada di pasar modal (Nguyen, et al., 2019). Persepsi risiko bersifat subjektif, sehingga keyakinan mengenai risiko akan berbeda tiap individu (Septyanto, 2013). Demikian halnya, tingkat literasi keuangan menentukan keputusan investasi individu. Seseorang yang memiliki tingkat literasi keuangan yang baik, memahami berbagai jenis instrumen investasi dan mampu mengelola investasi dengan bijak (Lusardi \& Mitchell, 2014). Penelitian ini menggunakan pengukuran literasi keuangan objektif yang mengacu pada pengetahuan aktual (Lim et al., 2018) sehingga menghasilkan keakuratan keputusan investasi (Kumar \& Goyal, 2015).

Berdasarkan rumusan masalah dan paparan motivasi, penelitian ini bertujuan untuk menganalisis faktor-faktor internal yang mampu mempengaruhi minat investasi di pasar modal dengan menggunakan pendekatan TPB. Dalam teori ini menjelaskan bahwa minat investasi diprediksikan sebagai faktor yang kuat dalam mempengaruhi perilaku individu untuk berinvestasi di pasar modal. Minat investasi diprediksi melalui faktor internal yang meliputi sikap, norma subjektif, persepsi kendali perilaku, literasi keuangan, dan persepsi risiko. Manfaat penelitian ini, pertama, memberikan sumbangan pemikiran terkait dengan minat investasi di pasar modal menggunakan pendekatan TPB. Kedua, hasil penelitian ini dapat memberikan saran kepada lembaga keuangan dan pemerintah untuk merancang program, pelatihan, atau seminar yang mampu meningkatkan literasi dan inklusi keuangan utamanya pada sektor pasar modal. 


\section{LANDASAN TEORI DAN PENGEMBANGAN HIPOTESIS Theory of Planned Behaviour (TPB)}

TPB merupakan perluasan dari Theory of Reasoned Action (TRA) (Ajzen, 1991) dengan penambahan konstruk yaitu persepsi kendali perilaku. TPB menjelaskan perilaku individu dapat diprediksi berdasarkan minat untuk melakukan perilaku (Ashidiqi \& Arundina, 2017). TPB menempatkan minat seseorang untuk berperilaku dipengaruhi oleh tiga faktor yaitu sikap, norma subjektif, dan persepsi kendali perilaku. Minat investasi diasumsikan sebagai kondisi yang dibutuhkan untuk bertindak secara sukarela yang dipicu oleh sikap investor, tekanan sosial, dan peluang atau hambatan yang dihadapai oleh individu (Alleyne \& Broome, 2011).

Sikap didefinisikan sebagai penilaian individu baik positif maupun negatif setelah melakukan suatu perilaku tertentu (Ajzen, 1991). Faktor penentu dari sikap adalah keyakinan terkait hasil atau manfaat yang akan diperoleh di masa depan sebagai akibat dari tindakan yang dilakukan (East, 1993). Apabila individu memiliki sikap yang menguntungkan terhadap perilaku tertentu, muncul peluang untuk mengembangkan minat positif berperilaku. Sikap individu pada saat investasi di pasar modal memainkan peran yang penting dalam mengembangkan minat untuk berinvestasi (Akhtar \& Das, 2018). Individu berkeyakinan bahwa dengan berinvestasi di pasar modal maka stabilitas keuangan akan tercapai (Alleyne \& Broome, 2011). Apabila individu memiliki sikap bahwa investasi di pasar modal adalah ide yang bagus, keputusan bijak, dan pada akhirnya akan memberikan hasil yang positif, maka ia akan menambah keyakinannya untuk investasi di pasar modal.

\section{H1: Sikap berpengaruh positif terhadap minat investasi di pasar modal}

Norma subjektif adalah tekanan sosial yang mendorong seseorang untuk terlibat maupun tidak terlibat dalam perilaku tertentu (Ajzen, 1991). Norma subjektif disebut juga sebagai keyakinan normatif, yaitu keyakinan bahwa tindakan yang dilakukan memperoleh dukungan dari orang terdekat (Machrus \& Purwono, 2010). Orang-orang terdekat yang berpotensi mempengaruhi perilaku seseorang adalah keluarga, rekan kerja, pasangan dan teman. Semakin besar tekanan sosial yang diberikan, maka semakin besar pula minat untuk melakukan sesuatu. Phan \& Zhou, (2014) menemukan bahwa individu tertarik berinvestasi di pasar modal, jika orang yang dekat dengan mereka memberikan nasihat atau berpikir bahwa mereka perlu berinvestasi. Semakin banyak keluarga, sahabat, dan rekan kerja yang memberikan saran dan dorongan untuk berinvestasi di pasar modal, maka semakin meningkatkan keyakinan individu untuk terlibat secara langsung berinvestasi di pasar modal.

\section{H2: Norma subjektif berpengaruh positif terhadap minat investasi di pasar modal}

Persepsi kendali perilaku didefinisikan sebagai persepi individu terkait dengan kemudahan atau kerumitan melakukan perilaku tertentu yang mencerminkan pengalaman masa lalu (Ajzen, 1991). Persepsi ini ditentukan oleh keyakinan kendali, bahwa individu dapat melakukan tindakan karena didukung oleh sumber daya yang ada (Machrus \& Purwono, 2010). Keyakinan kendali diukur dengan dua faktor yaitu kekuatan yang melandasi aksi dan akses kendali (Ajzen, 1991). Beberapa peneliti menemukan bahwa individu yang memiliki pengetahuan tentang investasi meningkatkan minat investasi di pasar modal (Alleyne \& Broome, 2011; Ashidiqi \& Arundina, 2017; East, 1993). Individu yang memiliki sumber daya seperti kemampuan dan pengetahuan dapat mengendalikan diri ketika dihadapkan dengan investasi sehingga memicu minat untuk 
melakukan investasi di pasar modal.

H3: Persepsi kendali perilaku berpengaruh positif terhadap minat investasi di pasar modal

\section{Literasi Keuangan}

Literasi keuangan merupakan kemampuan untuk menggunakan pengetahuan dan keterampilan dalam mengelola sumber daya keuangan secara efektif (Hastings, et al., 2013). Pengetahuan tentang keuangan merujuk pada pengetahuan produk keuangan (saham, obligasi, reksadana) dan pengetahuan konsep keuangan (inflasi, suku bunga, diversifikasi risiko, bunga majemuk) dalam rangka mencapai perencanaan keuangan yang baik. Tanpa memahami konsep keuangan, seseorang tidak memiliki bekal untuk membuat keputusan pengelolaan keuangan. Lebih lanjut, pengabaian terhadap pengetahuan keuangan memicu timbulnya biaya. Seseorang yang tidak memahami konsep bunga majemuk menghabiskan banyak biaya transaksi, memiliki hutang yang besar, dan dikenakan suku bunga pinjaman yang tinggi sehingga berimbas pada utang yang tinggi dan tabungan yang rendah (Lusardi \& Tufano, 2015).

Pada sisi lain, seseorang yang memiliki literasi keuangan yang baik maka ia memiliki kepercayaan diri untuk mengelola keuangan sehingga meningkatkan keputusan keuangan yang efektif (Pangestika \& Rusliati, 2019). Penelitian lain juga menemukan bahwa literasi keuangan berpengaruh signifikan terhadap minat untuk berpartisipasi di pasar modal (Allgood \&Walstad, 2016; Lim et al., 2018). Apabila individu memiliki pemahaman keuangan yang baik tentang instrumen di pasar modal, imbal hasil dan risiko keuangan, inflasi, suku bunga, dan mampu mengelola portofolio, maka semakin meningkatkan minat untuk berinvestasi di pasar modal. H4: Literasi keuangan berpengaruh positif terhadap minat investasi di pasar modal

\section{Persepsi Risiko}

Investasi selalu berkaitan dengan imbal hasil dan risiko. Keputusan untuk investasi di pasar modal harus dapat mengukur potensi adanya risiko. Besaran risiko yang dapat diterima oleh masing-masing individu dapat berbeda, bergantung pada persepsi individu terhadap risiko. Persepsi risiko merupakan penilaian individu pada suatu kondisi atau instrumen investasi yang berisiko (Wulandari \& Iramani, 2014). Persepsi risiko terbentuk dari kondisi sosial sehingga bergantung pada karakteristik psikologis dan kondisi yang melingkupinya (Williamson \& Weyman, 2005).

Persepsi risiko memainkan peran penting pada minat investasi utamanya dalam pengambilan keputusan pada kondisi tidak pasti (Vuk, et al., 2017). Individu akan lebih peka terhadap risiko ketika berhubungan dengan potensi kerugian investasi (Alleyne \& Broome, 2011). Jika individu semakin memahami risiko instrumen investasi di pasar modal dan dapat mengukur besar risiko yang dapat diterima, maka individu akan semakin berminat untuk investasi di pasar modal.

H5: Persepsi risiko berpengaruh positif terhadap minat investasi di pasar modal

\section{METODE PENELITIAN}

Penelitian ini merupakan jenis penelitian kuantitatif yang menguji faktor yang mempengaruhi minat 
investasi di pasar modal. Data penelitian diperoleh secara langsung melalui kuesioner yang disebarkan secara daring. Variabe yang digunakan dalam penelitian ini adalah variabel eksogen dan endogen. Definisi dan indikator variabel eksogen dan endogen yang digunakan dalam penelitian ini dijelaskan dalam Tabel 1.Variabel endogen yang digunakan dalam penelitian adalah minat investasi. Variabel eksogen yang digunakan dalam menjelaskan minat investasi teridiri atas sikap, norma subjektif, persepsi kendali perilaku, literasi keuangan, dan persepsi risiko. Masing-masing variabel berisi pernyataan yang diukur dengan skala likert 6 poin yaitu "sangat tidak setuju" (1) sampai dengan "sangat setuju" (6).

Populasi dalam penelitian ini adalah investor individual di pasar modal Indonesia. Teknik pengambilan sampel penelitian menggunakan nonprobability sampling, yaitu convenience sampling. Hipotesis yang diajukan dalam penelitian diuji dengan SEM melalui metode analisis jalur menggunakan bantuan SmartPLS 2.0.

Tabel 1. Definisi dan Indikator Variabel

\begin{tabular}{|c|c|c|c|c|}
\hline Variabel & & Definisi Operasional & Indikator & Referensi \\
\hline \multirow{5}{*}{ Eksogen } & Sikap & $\begin{array}{l}\text { Penilaian individu terkait } \\
\text { ketertarikannya untuk } \\
\text { investasi di pasar modal. }\end{array}$ & $\begin{array}{l}\text { S1:Investasi merupakan ide yang } \\
\text { bagus } \\
\text { S2: Investasi adalah pilihan yang } \\
\text { bijak } \\
\text { S3:Dampak positif investasi } \\
\text { S4:Persetujuan ide untuk investasi }\end{array}$ & $\begin{array}{l}\text { (Ajzen, 1991; } \\
\text { Akhtar \& Das, } \\
\text { 2018; Alleyne \& } \\
\text { Broome, 2011) }\end{array}$ \\
\hline & $\begin{array}{l}\text { Norma } \\
\text { Subjektif }\end{array}$ & $\begin{array}{l}\text { Persepsi individu terkait } \\
\text { sejauh mana lingkungan } \\
\text { sosial (teman, keluarga, } \\
\text { sahabat, rekan kerja) } \\
\text { mempengaruhi minat untuk } \\
\text { investasi di pasar modal. }\end{array}$ & $\begin{array}{l}\text { NS1:Orang terdekat yang } \\
\text { berinvestasi di pasar modal }\end{array}$ & $\begin{array}{l}\text { (Ajzen, 1991; } \\
\text { Akhtar \& Das, } \\
\text { 2018; Phan \& } \\
\text { Zhou, 2014) }\end{array}$ \\
\hline & $\begin{array}{l}\text { Persepsi } \\
\text { Kendali Perilaku }\end{array}$ & $\begin{array}{l}\text { Persepsi individu terkait } \\
\text { dengan kemudahan atau } \\
\text { kesulitan melakukan } \\
\text { perilaku tertentu. }\end{array}$ & $\begin{array}{l}\text { PKP1:Kemampuan berinvestasi } \\
\text { PKP2: Kendali penuh } \\
\text { PKP3:Pengetahuan dan kemampuan } \\
\text { berinvestasi }\end{array}$ & $\begin{array}{l}\text { (Ajzen, 1991; } \\
\text { Akhtar \& Das, } \\
\text { 2018; Ashidiqi \& } \\
\text { Arundina, 2017) }\end{array}$ \\
\hline & $\begin{array}{l}\text { Literasi } \\
\text { Keuangan }\end{array}$ & $\begin{array}{l}\text { Kemampuan individu dalam } \\
\text { menggunakan pengetahuan } \\
\text { dan keterampilan untuk } \\
\text { mengelola keuangan. }\end{array}$ & $\begin{array}{l}\text { LKO1:Diversifikasi risiko } \\
\text { LKO2:Inflasi } \\
\text { LKO3:Konsep bunga } \\
\text { LKO4:Bunga majemuk }\end{array}$ & $\begin{array}{l}\text { (Klapper, et al., } \\
\text { 2015; Lim et al., } \\
\text { 2018; van Rooij et } \\
\text { al., 2011) }\end{array}$ \\
\hline & Persepsi Risiko & $\begin{array}{l}\text { Keyakinan, sikap, dan } \\
\text { penilaian terkait dengan } \\
\text { risiko ketika berinvestasi di } \\
\text { pasar modal. }\end{array}$ & $\begin{array}{l}\text { PR1:Preferensi instrumen berisiko } \\
\text { PR2:Investasi pada aset yang aman } \\
\text { PR3:Instrumen aset yang } \\
\text { membahayakan } \\
\text { PR4:Instrumen risiko rendah }\end{array}$ & $\begin{array}{l}\text { (Hoffmann et al., } \\
\text { 2013; Nguyen et } \\
\text { al., 2019) }\end{array}$ \\
\hline Endogen & Minat Investasi & $\begin{array}{l}\text { Kecenderungan perilaku } \\
\text { untuk berinvestasi di pasar } \\
\text { modal. }\end{array}$ & $\begin{array}{l}\text { MI1:Frekuensi investasi } \\
\text { MI2:Dorongan kepada teman dan } \\
\text { keluarga untuk berinvestasi } \\
\text { MI3:Keinginan untuk berinvestasi } \\
\text { dalam jangka waktu dekat }\end{array}$ & $\begin{array}{l}\text { (Ajzen, 1991; } \\
\text { Akhtar \& Das, } \\
\text { 2018; Warsame \& } \\
\text { Ireri, 2016) }\end{array}$ \\
\hline
\end{tabular}

\section{HASIL PENELITIAN DAN PEMBAHASAN}

Data dalam penelitian diuji dengan menggunakan uji validitas dan reliabilitas untuk menentukan konstruk 
yang absah dan andal. Hipotesis yang diajukan diuji dengan menggunakan metode analisis jalur. Sampel yang digunakan dalam penelitian ini berjumlah 161 responden yang telah mengisi kuesioner dengan lengkap. Tabel 2 menunjukkan karakteristik demografi responden dalam penelitian.

Karakteristik demografi responden dikelompokkan menjadi beberapa kategori berdasarkan jenis kelamin, usia, pendidikan, pekerjaan, dan wilayah asal. Dari data demografi tersebut memberikan gambaran bahwa sebanyak 58,4\% responden berjenis kelamin laki-laki dan $41,6 \%$ berjenis kelamin perempuan. Responden yang memiliki usia kurang dari 20 tahun sebanyak 1,2\%, 20-30 tahun 45,9\%, 31-40 tahun sebanyak 34,2\%, 41-50 tahun sebanyak 18\%, dan usia diatas 50 tahun sebanyak 0,7\%. Jika dilihat dari tingkat pendidikan, responden yang duduk dibangku SMA sebanyak 1,9\%, tingkat Sarjana (S1) sebanyak 57,8\%, dan Magister (S2) sebesar 40,3\%. Sebaran pekerjaan responden terdiri atas pelajar/mahasiswa 7,5\%, PNS 29,2\%, karyawan swasta $37,9 \%$, wirausaha $18 \%$ dan lainnya sebesar $7,4 \%$. Sejumlah $73,9 \%$ berasal dari Jawa dan $26,1 \%$ berasal dari luar Jawa.

Tabel 2. Demografi Responden

\begin{tabular}{llcc}
\hline \multirow{2}{*}{ Karakteristik demografi } & Jumlah $(\mathrm{n}=161)$ & $\%$ \\
\hline \multirow{2}{*}{ Jenis kelamin } & Laki-laki & 94 & 58,4 \\
& Perempuan & 67 & 41,6 \\
\hline \multirow{4}{*}{ Usia } & $<20$ & 2 & 1,2 \\
& $20-30$ & 74 & 45,9 \\
& $31-40$ & 55 & 34,2 \\
& $41-50$ & 29 & 18,0 \\
\multirow{4}{*}{ Pendidikan } & $>50$ & 1 & 0,7 \\
\hline \multirow{4}{*}{ Pekerjaan } & SMA & 3 & 1,9 \\
& S1 & 93 & 57,8 \\
& S2 & 65 & 40,3 \\
\hline & Pelajar/Mahasiswa & 12 & 7,5 \\
& PNS & 47 & 29,2 \\
& Karyawan swasta & 61 & 37,9 \\
& Wirausaha & 29 & 18,0 \\
& Lainnya & 12 & 7,4 \\
& Jawa & 119 & 73,9 \\
& Luar Jawa & 42 & 26,1
\end{tabular}

Sumber: Data Primer Diolah (2020)

Data penelitian yang diperoleh dari responden diuji validitas dan reliabilitas. Uji validitas bertujuan untuk mengetahui keabsahan instrumen dalam kuesioner. Instrumen dinyatakan absah jika nilai loading factor $>0,7$ dan nilai Average Variance Extracted (AVE) > 0,5 (Ghozali \& Latan, 2015). Keseluruhan indikator yang diajukan dalam penelitian ini berjumlah 20, namun terdapat 2 indikator (LKO4 dan PR3) dengan nilai loading factor kurang dari 0,7. Dua indikator dieliminasi, sehingga tidak digunakan dalam pengujian selanjutnya. Total indikator yang digunakan berjumlah 18.

Indikator yang telah lolos uji validitas, kemudian diuji reliabilitas. Uji reliabilitas ditujukan untuk melihat kestabilan responden menjawab konstruk pernyataan yang diberikan dalam kuesioner. Sebuah konstruk 
dikatakan reliabel apabila nilai Composite Reliability $(C R)>0,7$ dan nilai Cronbach's Alpha > 0,6 (Ghozali \& Latan, 2015). Hasil pengujian menunjukkan bahwa seluruh konstruk memiliki nilai CR lebih dari 0,7 dan Cronbach's Alpha lebih dari 0,6 sehingga dikatakan semua konstruk reliabel. Keseluruhan hasil pengujian validitas dan reliabilitas ditampilkan pada Tabel 3.

Setelah melakukan uji validitas dan reliabilitas, data penelitian diuji menggunakan SEM dengan metode analisis jalur. Apabila nilai t-statistics lebih dari 1,96 dan arah koefisien sesuai dengan yang dihipotesiskan, maka hipotesis terdukung. Hasil menunjukkan bahwa terdapat 3 dari 5 jalur yang diajukan memiliki nilai t-statistics $>$ 1,96 dan arah koefisien seperti hipotesis yang diajukan artinya hipotesis terdukung. Secara lebih rinci, pengaruh antara sikap (S) terhadap minat investasi (MI) menunjukkan koefisien positif sebesar 0,099 dan t-statistics < 1,96 yaitu 0,951. Pada hipotesis kedua pengaruh norma subjektif (NS) terhadap minat investasi (MI) menunjukkan koefisien negatif-0,119 dan t-statistics 1,603.

Hipotesis ketiga menunjukkan path persepsi kendali perilaku (PKP) ke minat investasi (MI) dengan koefisien positif sebesar 0,222 dan t-statistics > 1,96 sebesar 2,472. Pengaruh literasi keuangan (LKO) terhadap minat investasi (MI) ditunjukkan melalui koefisien positif sebesar 0,362 dan t-statistics > 1,96 sebesar 4,037. Pada jalur terakhir, yaitu persepsi risiko (PR) terhadap minat investasi (MI) menunjukkan koefisien 0,376 dan t-statistics $>1,96$ yaitu 3,966. Keseluruhan model yang diajukan dalam penelitian ini menghasilkan nilai $R$ Square sebesar 0,771, artinya variabel yang diajukan dapat menjelaskan minat investasi sebesar 77,1\%.

Hasil pengujian hipotesis pertama menunjukkan bahwa sikap tidak memiliki pengaruh terhadap minat investasi di pasar modal, sehingga $\mathrm{H} 1$ tidak terdukung. Penelitian ini menujukkan bahwa sikap tidak menentukan minat individu untuk melakukan investasi di pasar modal. Keyakinan akan hasil yang diperoleh di masa yang akan datang dari investasi tidak membuat individu tertarik secara langsung untuk berinvestasi di pasar modal. Selain itu, Ashidiqi \& Arundina (2017) dan Akhtar \& Das (2018) menemukan bahwa sikap tidak berpengaruh secara langsung terhadap minat, namun sikap ditentukan oleh faktor lain seperti pengetahuan, religiusitas, risiko dan imbal hasil, dan reputasi, sehingga hal ini mendukung temuan penelitian bahwa sikap tidak berpengaruh secara langsung terhadap minat investasi

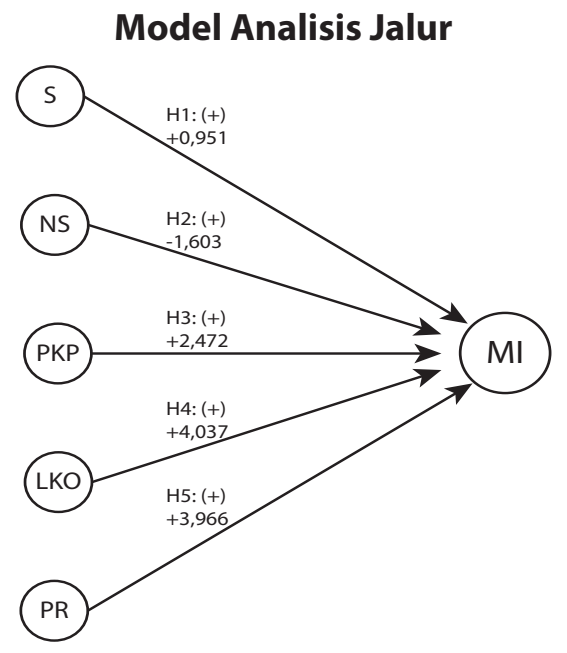

Faktor yang Mempengaruhi Minat Investasi Di Pasar Modal: Pendekatan Theory Of Planned Behaviour 
Tabel 3. Hasil Uji Validitas dan Reliabilitas

\begin{tabular}{|c|c|c|c|c|}
\hline Indikator & Loading factor & AVE & CR & Cronbach's Alpha \\
\hline Sikap & & 0,612 & 0,863 & 0,789 \\
\hline S1 & 0,796 & & & \\
\hline S2 & 0,790 & & & \\
\hline S3 & 0,775 & & & \\
\hline S4 & 0,770 & & & \\
\hline Norma Subjektif & & 0,808 & 0,894 & 0,762 \\
\hline NS1 & 0,892 & & & \\
\hline NS2 & 0,906 & & & \\
\hline Persepsi kendali perilaku & & 0,568 & 0,798 & 0,621 \\
\hline PKP1 & 0,760 & & & \\
\hline PKP2 & 0,730 & & & \\
\hline PKP3 & 0,771 & & & \\
\hline Literasi keuangan & & 0,653 & 0,849 & 0,735 \\
\hline LKO1 & 0,830 & & & \\
\hline LKO2 & 0,770 & & & \\
\hline LKO3 & 0,822 & & & \\
\hline Persepsi risiko & & 0,621 & 0,831 & 0,697 \\
\hline PR1 & 0,767 & & & \\
\hline PR2 & 0,806 & & & \\
\hline PR4 & 0,790 & & & \\
\hline Minat investasi & & 0,660 & 0,853 & 0,742 \\
\hline MI1 & 0,824 & & & \\
\hline MI2 & 0,829 & & & \\
\hline MI3 & 0,783 & & & \\
\hline
\end{tabular}

Sumber: Data Primer Diolah (2020)

Pengujian hipotesis kedua menunjukkan bahwa norma subjektif tidak memiliki pengaruh terhadap minat investasi, $\mathrm{H} 2$ tidak terdukung. Pengaruh dari orang-orang terdekat tidak lantas memacu minat individu untuk melakukan investasi. Meskipun terdapat dorongan atau nasihat yang diberikan, keputusan untuk investasi tetap berada di tangan individu, sehingga tekanan dari lingkungan tidak berpengaruh secara langsung pada minat individu untuk investasi. Hasil penelitian sejalan dengan Warsame \& Ireri (2016) yang menemukan bahwa norma subjektif tidak berpengaruh pada minat investasi.

Tabel 4. Hasil Pengujian menggunakan SEM

\begin{tabular}{lccc}
\hline \multicolumn{1}{c}{ Hipotesis } & Koefisien jalur & t-statistics & Keputusan \\
\hline H1: S à MI & 0,099 & 0,951 & Tidak terdukung \\
H2: NS à MI & $-0,119$ & 1,603 & Tidak terdukung \\
H3: PKP à MI & 0,222 & 2,472 & Terdukung \\
H4: LKO à MI & 0,362 & 4,037 & Terdukung \\
H5: PR à MI & 0,376 & 3,966 & Terdukung \\
R $^{2}=0,771$ & & & \\
\hline
\end{tabular}

Sumber: Data Primer Diolah (2020) 
Persepsi kendali perilaku ditemukan memiliki pengaruh positif terhadap minat investasi, sehingga $\mathrm{H} 3$ terdukung. Tingginya persepsi kendali berpengaruh dengan tingginya minat investasi. Sumber daya internal dan eksternal berupa pengetahuan, pelatihan, dan keterampilan yang diperoleh memudahkan individu untuk terlibat langsung dalam investasi, sehingga meningkatkan minat investasi di pasar modal. Sejalan dengan TPB, kemudahan dalam investasi tercipta karena memiliki pengalaman, sehingga mendorong minat untuk investasi. Sejalan dengan Alleyne \& Broome (2011); Ashidiqi \& Arundina (2017); East (1993); Warsame \& Ireri (2016) yang menyatakan jika persepsi kendali perilaku berpengaruh positif terhadap minat investasi.

Pengujian hipotesis keempat menampilkan literasi keuangan memiliki pengaruh positif terhadap minat invetasi, sehingga H4 terdukung. Semakin tinggi literasi keuangan seseorang maka semakin tinggi minat untuk investasi. Seseorang yang memiliki pengetahuan keuangan yang baik, dapat mengelola keuangannya, sehingga meningkatkan kepercayaan dirinya untuk berinvestasi. Selain itu, dengan literasi keuangan yang tinggi, maka mengurangi biaya untuk bekerja sama dengan penasihat investasi. Hasil penelitian ini sejalan dengan Darmawan, et al. (2019); Lusardi \& Mitchell (2011); Pangestika \& Rusliati (2019); van Rooij et al. (2011) yang menyebutkan bahwa literasi keuangan berpengaruh positif terhadap minat investasi.

Hasil pengujian hipotesis kelima menunjukkan persepsi risiko berpengaruh positif terhadap minat investasi, sehingga $\mathrm{H} 5$ terdukung. Semakin tinggi persepsi atas risiko yang dimiliki seseorang, maka semakin tinggi pula minat untuk investasi. Seseorang yang memiliki persepsi risiko yang tinggi memahami risiko masingmasing instrumen dan mampu mengukur risiko investasi, sehingga ia akan berinvestasi pada instrumen yang aman (Hoffmann et al., 2013). Melalui persepsi risiko yang tinggi pula, individu akan tertarik untuk berinvestasi dan mampu mencegah potensi kerugian. Temuan penelitian ini sejalan dengan Lim et al. (2018); Sokolowska \& Makowiec (2017); Vuk et al. (2017) yang menemukan bahwa persepsi risiko berpengaruh positif terhadap minat investasi.

\section{KESIMPULAN}

Tujuan penelitian adalah menganalisis faktor internal yang dapat mempengaruhi minat investasi di pasar modal. Minat investasi diprediksi melalui pendekatan TPB. Variabel yang digunakan untuk memprediksi minat investasi meliputi sikap, norma subjektif, persepsi kendali perilaku, literasi keuangan, dan persepsi risiko. Berdasarkan hasil pengujian yang dilakukan menunjukkan bahwa persepsi kendali perilaku, literasi keuangan, dan persepsi risiko memiliki pengaruh positif terhadap minat investasi. Namun, ada beberapa faktor yang ditemukan memiliki hasil berbeda dengan yang diajukan yaitu, sikap dan norma subjektif. Sikap dan norma subjektif ditemukan tidak memiliki pengaruh terhadap minat investasi di pasar modal.

Implikasi penelitian ini bagi investor dan lembaga pasar modal di Indonesia bahwa faktor intrinsik yang meningkatkan minat individu untuk investasi di pasar modal adalah persepsi kendali perilaku, literasi keuangan, dan persepsi risiko. Ketiga faktor tersebut ditemukan memiliki pengaruh yang signifikan terhadap minat investasi. Bagi individu, dengan pengetahuan, keterampilan, dan pemahaman akan risiko mampu mendorong keinginan untuk terlibat secara langsung berinvestasi. Hasil penelitian ini diharapkan menjadi bahan literatur bagi peneliti selanjutnya yang ingin memperdalam hasil penelitian sehingga mampu memberikan kegunaan 
bagi kemajuan pasar modal di Indonesia.

Saran untuk penelitian selanjutnya meliputi:(1) melakukan penelitian sejenis dengan metode penelitian lain yaitu metode eksperimen, sehingga dapat diketahui dengan lebih realistis faktor yang mempengaruhi minat investasi. Selain itu, dengan penelitian eksperimen, dapat secara aktual menggambarkan perilaku yang mempengaruhi minat investasi; (2) memperbanyak jumlah sampel untuk memperluas generalisasi hasil penelitian; (3) menambahkan variabel atau model lain yang dapat memprediksi minat invetasi di pasar modal Indonesia; (3) melakukan pengujian lebih lanjut berdasarkan kelompok atau jenis pekerjaan agar diketahui secara pasti kelompok yang memiliki minat investasi yang rendah sehingga dapat memberikan saran kepada pihak yang berkepentingan untuk meningkatkan literasi keuangan.

\section{DAFTAR PUSTAKA}

Ackert, L. F., Church, B. K., Ackert, L. F., \& Church, B. K. (2010). Firm Image and Individual Investment Decisions Firm Image and Individual Investment Decisions. (May 2015), 37-41.

Ajzen, I. (1991). The theory of planned behavior. Organizational Behavior and Human Decision Processes, 50, 179-211.

Akhtar, F., \& Das, N. (2018). Predictors of investment intention in Indian stock markets: Extending the theory of planned behaviour. International Journal of Bank Marketing, 37(1), 97-119.

Alleyne, P., \& Broome, T. (2011). Using the Theory of Planned Behaviour and Risk Propensity to Measure Investment Intentions among Future Investors. Journal of Eastern Caribbean Studies, 36(1), 1-20.

Allgood, S., \& Walstad, W. B. (2016). The effects of perceived and actual financial literacy on financial behaviors. Economic Inquiry, 54(1), 675-697.

Ashidiqi, C., \& Arundina, T. (2017). Indonesia Students's intention to invest in Sukuk: Theory of planned behaviour approach. International Journal of Economic Research, 14(15), 395-407.

Aspara, J. (2013). The Role of Product and Brand Perceptions In Stock Investing: Effects On Investment Considerations, Optimism and Confidence. Journal of Behavioral Finance, 14(3), 195-212.

BPS. (2019). Statistik Indonesia 2019. Jakarta: Badan Pusat Statistik.

Cohen, J., Holder-Webb, L., \& Khalil, S. (2017). A Further Examination of the Impact of Corporate Social Responsibility and Governance on Investment Decisions. Journal of Business Ethics, 146(1), $203-218$.

Combrink, S., \& Lew, C. (2019). Potential Underdog Bias, Overconfidence and Risk Propensity in Investor Decision-Making Behavior. Journal of Behavioral Finance, 1-15.

Daneshvar, M. E., Khoshkhoo, O. I., Aminian, A., \& Malekmohammadi, E. (2017). Investigating the Effective Factors on Investment Intention of Individuals in the Stock Exchange (Case Study: Individual Investors in Arak City). International Journal of Economic Perspectives, 11(1), 808-815.

Darmawan, A., Kurnia, K., \& Rejeki, S. (2019). Pengetahuan Investasi, Motivasi Investasi, Literasi Keuangan Dan Lingkungan Keluarga Pengaruhnya Terhadap Minat Investasi Di Pasar Modal. Jurnal IImiah Akuntansi Dan Keuangan, 8(2), 44-56. 
Djojopranoto, R. R., \& Mahadwartha, P. A. (2016). Pengujian Bias Perilaku: Gambler'S Fallacy, Halo Effect, Dan Familiarity Effect Di Pasar Modal Indonesia. Jurnal Akuntansi Dan Keuangan Indonesia, 13(2), 142-159.

East, R. (1993). Investment decisions and the theory of planned behaviour. Journal of Economic Psychology, 14(2), 337-375.

Elliott, W. B., Jackson, K. E., Peecher, M. E., \& White, B. J. (2014). The unintended effect of Corporate Social Responsibility performance on investors' estimates of fundamental value. Accounting Review, 89(1), 275-302.

Ghozali, I., \& Latan, H. (2015). Partial Least Squares Konsep, Teknik dan Aplikasi MEnggunakan Program SmartPLS 3.0 (2nd ed.). Semarang: Badan Penerbit UNDIP.

Hastings, J. S., Madrian, B. C., \& Skimmyhorn, W. L. (2013). Financial literacy, financial education, and economic outcomes. Annual Review of Economics, 5, 347-373.

Hoffmann, A. O. I., Post, T., \& Pennings, J. M. E. (2013). Individual investor perceptions and behavior during the financial crisis. Journal of Banking and Finance, 37(1), 60-74.

Hoffmann, A. O. I., Post, T., \& Pennings, J. M. E. (2015). How Investor Perceptions Drive Actual Trading and RiskTaking Behavior. Journal of Behavioral Finance, 16(1), 94-103.

Klapper, L., Lusardi, A., \& Oudheusden, P. (2015). Financial Literacy Around the World: Insight From The Standard \& Poor's Ratings Services Global Financial Literacy Survey.

Kumar, S., \& Goyal, N. (2015). Behavioural biases in investment decision making - a systematic literature review. Qualitative Research in Financial Markets, 7(1), 88-108.

Kustodian Sentral Efek Indonesi. (2019). Laporan Kinerja Direksi. 1-116.

Lim, T. S., Mail, R., Abd Karim, M. R., Ahmad Baharul Ulum, Z. K., Jaidi, J., \& Noordin, R. (2018). A serial mediation model of financial knowledge on the intention to invest: The central role of risk perception and attitude. Journal of Behavioral and Experimental Finance, 20, 74-79.

Listyani, T. T., Rois, M., \& Prihati, S. (2019). Analisis Pengaruh Pengetahuan Investasi, Pelatihan Pasar Modal, Modal Investasi Minimal Dan Persepsi Risiko Terhadap Minat Investasi Mahasiswa Di Pasar Modal (Studi Pada Pt Phintraco Sekuritas Branch Office Semarang). Jurnal Aktual Akuntansi Keuangan Bisnis Terapan, 2(1), 49-70.

Lusardi, A., \& Mitchell, O. S. (2011). Financial literacy around the world: An overview. Journal of Pension Economics and Finance, 10(4), 497-508.

Lusardi, A., \& Mitchell, O. S. (2014). The economic importance of financial literacy: Theory and evidence. Journal of Economic Literature, 52(1), 5-44.

Lusardi, \& Tufano, P. (2015). Debt literacy, financial experiences, and overindebtedness. Journal of Pension Economics \& Finance, 14(4), 332-368.

Machrus, H., \& Purwono, U. (2010). Pengkuran Perilaku berdasarkan Theory of Planned Behavior. INSAN, 12(April), 64-71.

Narsa, I. M., Narsa, N. P. D. R. H., \& Prananjaya, K. P. (2020). An experimental study of the effect of financial and non-financial information on intention to invest in the bearish and bullish market. International Journal 
of Innovation, Creativity and Change, 11(11), 421-439.

Nguyen, L., Gallery, G., \& Newton, C. (2019). The joint influence of financial risk perception and risk tolerance on individual investment decision-making. Accounting and Finance, 59(S1), 747-771.

Pangestika, T., \& Rusliati, E. (2019). Literasi Dan Efikasi Keuangan Terhadap Minat Mahasiswa Berinvestasi Di Pasar Modal. Jurnal Riset Bisnis Dan Manajemen, 12(1), 37.

Phan, K. C., \& Zhou, J. (2014). Vietnamese Individual Investors' Behavior in the Stock Market: An Exploratory Study. Research Journal of Social Science \& Management, (April), 12.

Pradhana, R. W. (2018). Financial literacy , cognitive bias ,. Jurnal Ilmu Manajemen, 6, 108-117.

Septyanto, D. (2013). Faktor-Faktor Yang Mempengaruhi Investor Individu Dalam Pengambilan Keputusan Investasi Sekuritas Di Bursa Efek Indonesia (BEI). Jurnal Ekonomi, 4(2), 90-101.

Sokolowska, J., \& Makowiec, P. (2017). Risk preferences of individual investors: The role of dispositional tendencies and market trends. Journal of Behavioral and Experimental Economics , 71(September), 6778.

van Rooij, M., Lusardi, A., \& Alessie, R. (2011). Financial literacy and stock market participation. Journal of Financial Economics, 101(2), 449-472.

Vuk, K., Pifar, A., \& Aleksić, D. (2017). Should I, Would I, Could I: Trust and Risk Influences on Intention To Invest. Dynamic Relationships Management Journal, 6(1), 61-67.

Warsame, M. H., \& Ireri, E. M. (2016). Does the theory of planned behaviour (TPB) matter in Sukuk investment decisions? Journal of Behavioral and Experimental Finance, 12, 93-100.

Williamson, J., \& Weyman, A. (2005). Review of the Public Perception of Risk, and Stakeholder Engagement. Health and Safety Laboratory, 47.

Wulandari, D. A., \& Iramani, R. (2014). Studi Experienced Regret, Risk Tolerance , Overconfidance. Journal of Business and Banking, 4(1), 55-66. 